\title{
The immunological evaluation of levamisole treatment in cancer patients
}

\author{
H. VERHAEGEN* \\ M.D., Ph.D. \\ W. DE COCK* \\ M.Sc. \\ J. DE CREE* \\ M.D. \\ F. VERBRUGGEN* \\ A. DE BeukelaAR $\dagger$ \\ M.D. \\ F. KRUG† \\ M.D. \\ *Clinical Research Unit, St Bartholomeus, and \\ †Department of Internal Medicine, St Bartholomeus Hospital, B-2060 Merksem (Antwerp), Belgium
}

\begin{abstract}
Summary
The effect of levamisole on different immunological parameters was studied in patients with various malignant diseases.

Levamisole restored tuberculin-negative delayed hypersensitivity reactions and increased the sensitivity to 1-nitro-2,4-dichlorobenzene challenges. It also increased low E-rosette formation of T-lymphocytes and enhanced the clearance of a lipid emulsion by the reticulo-endothelial system.

Levamisole had no effect on serum immunoglobulin levels but increased serum haemolytic complement activity.
\end{abstract}

\section{Introduction}

In recent years the occurrence of humoral and cellular immune reactions against tumour antigens has been well established. The immune status seems to be normal in patients with early cancer, whilst it may be depressed in patients with advanced cancer as measured by delayed hypersensitivity reactions (Anthony et al., 1974; Eilber and Morton, 1970), lymphoblast transformation tests (Cheema and Hersch, 1971; Whittaker, Rees and Clark, 1971; Suciu-Foca et al., 1973; Twomey, Catalona and Chretien, 1974) or by the E-rosette test (Anthony et al., 1975; Dellon, Potvin and Chretien, 1975; Elhilali et al., 1976; Gross et al., 1975; Whitehead et al., 1976; Wybran and Fudenberg, 1973). Since depressed immunity seems to be associated with a bad prognosis, immunotherapy might well be a rational approach in cancer therapy. Different modes of immunotherapy-passive, adoptive, active - have been proposed, excellently reviewed

Correspondence: H. Verhaegen, M.D., Clinical Research Unit, St-Bartholomeus, Elf Novemberstraat 43, B-2060 Merksem (Antwerp), Belgium. by Bluming (1975). Of these, the non-specific active therapy with B.C.G. seems to be a value although results are controversial and side effects are a serious disadvantage. Other non-specific active immunotherapeutics currently under evaluation are Corynebacterium parvum, polyinosinic-cytidylic acid and, very recently, levamisole.

Renoux and Renoux (1971) reported that the anthelmintic drug levamisole increased the protective effect of a bacterial vaccine in mice. Two years later the present authors found that a 3-day treatment course with levamisole could restore delayed hypersensitivity reactivity to purified protein derivative (PPD) in patients with various debilitating diseases (Verhaegen et al., 1973; Brugmans et al., 1973). Since then, the effects of levamisole on different parameters of humoral and cellular immunity have been extensively studied and excellently reviewed by Oettgen, Pinsky and Delmonte (1976) and Symoens and Rosenthal (1977).

In tumour-bearing animals (Chirigos, Pearson and Fuhrman, 1974; Chirigos, Fuhrman and Pryor, 1975; Perk et al., 1975) and cancer patients (Amery, 1976; Rojas et al., 1976) levamisole therapy has shown promising results on the course of the disease. Experience with levamisole in human tumour immunology is now reported.

Materials and methods

Delayed hypersensitivity reaction to tuberculin

Sixty tuberculin-negative patients with various malignant diseases were selected at random. Forty were treated with a single oral dose of $150 \mathrm{mg}$ of levamisole for 3 consecutive days and twenty with placebo.

Tuberculin response was measured by the 
Mantoux test. Ten i.u. of PPD* were injected intradermally and readings were taken $48 \mathrm{hr}$ later without knowledge of the medication. A test was considered positive when the diameter of induration was at least $5 \mathrm{~mm}$.

The interval between the selection and the subsequent test was one week. The first dose of levamisole was given $48 \mathrm{hr}$ after the first PPD injection.

\section{Delayed hypersensitivity reaction to dinitrochloro- benzene}

One hundred and five patients with various malignant diseases were sensitized with $2 \mathrm{mg}$ of 1-nitro-2,4-dichlorobenzene in aerosol (DNCB) and challenged with $200,100,50$, and $25 \mu \mathrm{g}$ DNCB in aerosol 14 days later. Readings were taken after $48 \mathrm{hr}$ and a test was considered positive for a given dose when the diameter of induration was at least half as large $(\geqslant 7.5 \mathrm{~mm})$ as the sensitized area.

Thirty-nine patients received $150 \mathrm{mg}$ of levamisole/ day for the time of follow-up, forty-one patients received $150 \mathrm{mg}$ of levamisole for 3 consecutive days repeated every fortnight and twenty-five patients received placebo daily.

When the patients were seen again in the outpatient department, they were challenged with those doses of DNCB to which they were previously negative. The observer did not know the medication.

Forty-seven patients treated with levamisole could be followed-up for more than one year.

\section{Lipofundin clearance test}

The lipofundin clearance test was performed on twelve cancer patients before and 1-2 weeks after treatment with $150 \mathrm{mg}$ of levamisole/day. Measurements were performed blind.

This test was performed using a modified method after Lemperlee, Reichelt and Denk (1971). Fifty ml of lipofundin-S-20 (B. Braum, Melsurgen, Germany) was injected intravenously within $2 \mathrm{~min}$ and blood samples of $1.6 \mathrm{ml}$ in $0.4 \mathrm{ml}$ citrate were taken before and after 2, 4, 6, 8 and $10 \mathrm{~min}$ of injection. After dilution with $4 \mathrm{ml}$ saline, the samples were centrifuged for $2 \mathrm{~min}$ at $2500 \mathrm{rev} / \mathrm{min}$ and after appropriate dilution the turbidity of the supernatant was measured spectrophotometrically.

The half-life of the lipid $\left(T_{1 / 2}\right)$ was calculated on a semi-logarithmic chart.

\section{Immunoglobulins}

In eighty cancer patients, serum levels of IgA, IgG and IgM were determined before and after treatment with $150 \mathrm{mg}$ of levamisole daily for various periods

\footnotetext{
* Albumose-free tuberculin, Swiss Serotherapeutic and Vaccine Institute, Bern (Switzerland).
}

of time ranging from 1 week to 4 months. Measurements were performed blind. The radial immuno- $\propto$ diffusion technique of Mancini, Carbonara and $\subseteq$ Heremans (1965) was used with commercial plates $\overrightarrow{\vec{s}}$ and standards (Behringwerke AG).

\section{Serum complement}

The study was composed of ninety-one cancer $\frac{\vec{D}}{\vec{D}}$ patients; fifty-eight were treated with a single oral $\propto$ dose of $150 \mathrm{mg}$ of levamisole daily for 1-2 weeks $\tilde{\omega}$ and thirty-three were treated with placebo.

Haemolytic complement activity $\left(\mathrm{CH}_{50}\right)$ was determined by a modified method of Mayer (1971) $\vec{\omega}^{\circ}$ and complement components $\mathrm{C}_{3}, \mathrm{C}_{4}$ and $\mathrm{C}_{1 \mathrm{q}}$ by the radial immunodiffusion technique of Mancini $\frac{0}{3}$ et al. (1965) as described by Verhaegen et al. (1976).

\section{E-rosette forming cells}

Sixty-two patients with various malignant diseases participated in the study. Thirty-four were treated with a single oral dose of $150 \mathrm{mg}$ levamisole daily for 0 one week and twenty-eight patients were similarly treated with a placebo. Peripheral E-rosette forming cells (RFC) were assessed before and after treatment $\mathbb{\mathbb { D }}$ as described by Verhaegen et al. (1977b).

\section{Allocation of the patients}

The patients were randomly allocated to placebo and levamisole groups, but randomization was ng. fully stratified by tumour type. In the delaye hypersensitivity studies and the complement study a representative number of patients, i.e. about one third of the total number of selected patients, were allocated to the placebo groups. In the E-rosette study about equal numbers of patients were allocated to placebo and levamisole groups.

\section{Concomitant treatment}

In all studies reported, patients were not allowed to take cytostatic drugs, except the forty-seven patients in the DNCB study who were followed-up for more than one year.

\section{Statistical analysis}

Intergroup differences were analysed by the Mann-Whitney U test (Siegel, 1956a). Intragroup differences were analysed by the Wilcoxon matchedpairs signed-ranks test (Siegel, 1956b).

\section{Results}

\section{Delayed hypersensitivity reaction to tuberculin}

Out of forty tuberculin-negative cancer patients treated with $150 \mathrm{mg}$ of levamisole for 3 consecutive days, twelve were converted to a PPD-positive reaction, whereas out of twenty placebo-treated patients only one became positive at the second test. This difference is significant at the $5 \%$ level. 
TABLE 1. Distribution of the patients per tumour site, treatment and extension of the disease in the different studies

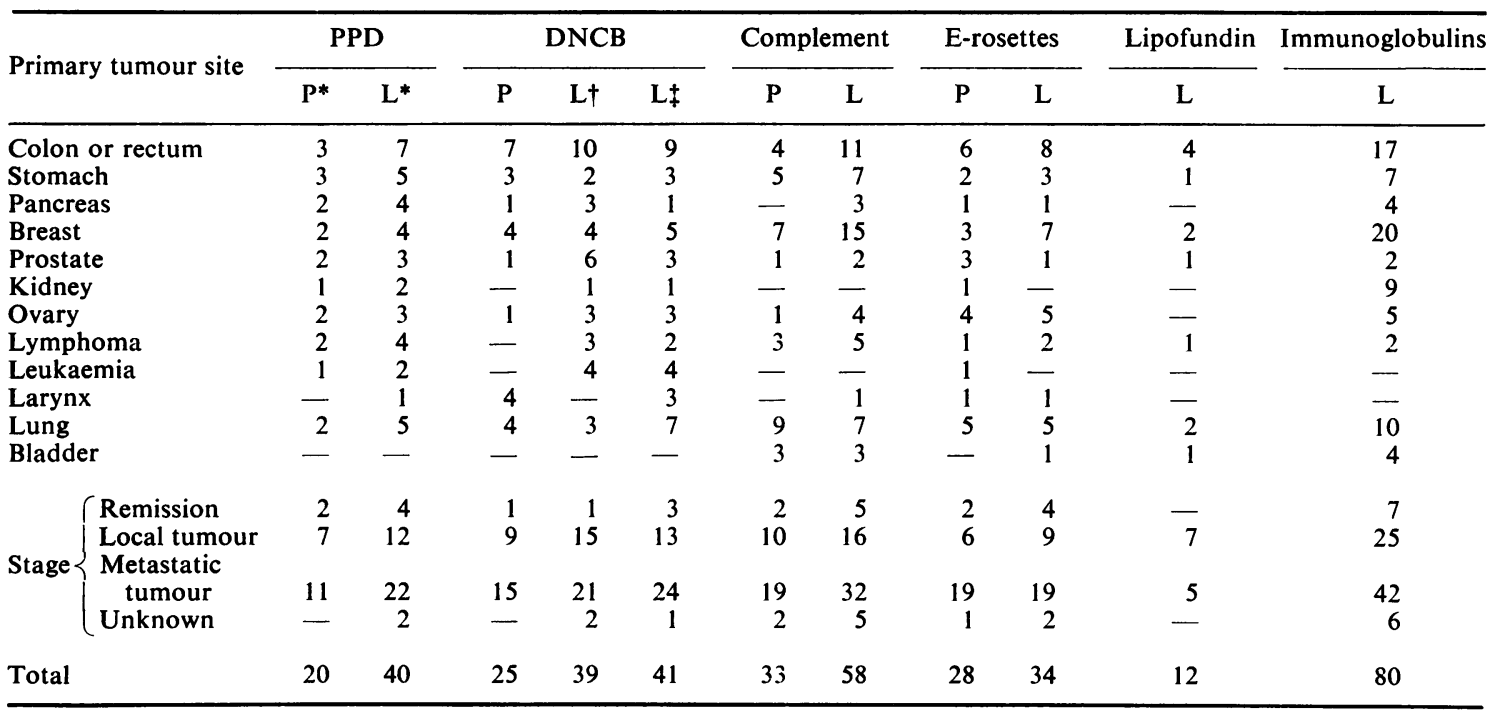

* $P=$ placebo treated controls; $L=$ patients treated with levamisole.

$\dagger \mathrm{L}=$ continuous levamisole treatment.

$\ddagger \mathbf{L}=$ intermittent levamisole treatment.

PPD $=$ purified protein derivative.

DNCB = 1-nitro-2,4-dichlorobenzene.

TABLE 2. Increased skin sensitivity to 1-nitro-2,4-dichlorobenzene after levamisole treatment

\begin{tabular}{|c|c|c|c|c|c|c|c|c|c|}
\hline \multirow[b]{2}{*}{$\begin{array}{l}\text { Primary } \\
\text { tumour site }\end{array}$} & \multicolumn{3}{|c|}{ Placebo } & \multicolumn{3}{|c|}{ Levamisole continuously } & \multicolumn{3}{|c|}{ Levamisole discontinuously } \\
\hline & $\begin{array}{l}\text { No. of } \\
\text { patients }\end{array}$ & $\begin{array}{l}\text { No. of } \\
\text { tests }\end{array}$ & $\begin{array}{c}\text { No. of } \\
\text { patients } \\
\text { with } \\
\text { increased } \\
\text { sensitivity }\end{array}$ & $\begin{array}{l}\text { No. of } \\
\text { patients }\end{array}$ & $\begin{array}{l}\text { No. of } \\
\text { tests }\end{array}$ & $\begin{array}{l}\text { No. of } \\
\text { patients } \\
\text { with } \\
\text { increased } \\
\text { sensitivity }\end{array}$ & $\begin{array}{l}\text { No. of } \\
\text { patients }\end{array}$ & $\begin{array}{l}\text { No. of } \\
\text { tests }\end{array}$ & $\begin{array}{l}\text { No. of } \\
\text { patients } \\
\text { with } \\
\text { increased } \\
\text { sensitivity }\end{array}$ \\
\hline Colon or rectum & 7 & 29 & 0 & 10 & 43 & 1 & 9 & 44 & 6 \\
\hline Stomach & 3 & 11 & 0 & 2 & 9 & 0 & 3 & 12 & 3 \\
\hline Pancreas & 1 & 3 & 0 & 3 & 15 & 0 & 1 & 4 & 1 \\
\hline Lung & 4 & 27 & 0 & 3 & 13 & 1 & 7 & 30 & 3 \\
\hline Breast & 4 & 15 & 0 & 4 & 14 & 1 & 5 & 19 & 3 \\
\hline Prostate & 1 & 6 & 0 & 6 & 21 & 1 & 3 & 12 & 2 \\
\hline Kidney & - & 一 & - & 1 & 4 & 0 & 1 & 3 & 0 \\
\hline Ovary & 1 & 7 & 0 & 3 & 18 & 0 & 3 & 11 & 1 \\
\hline Lymphoma & - & - & - & 3 & 11 & 0 & 2 & 9 & 1 \\
\hline Leukaemia & - & - & - & 4 & 10 & 1 & 4 & 9 & 2 \\
\hline Larynx & 4 & 13 & 0 & - & - & - & 3 & 12 & 3 \\
\hline Total & 25 & 111 & 0 & 39 & 158 & 5 & 41 & 165 & 25 \\
\hline
\end{tabular}

Delayed hypersensitivity reaction to dinitrochlorobenzene

After sensitization none of the placebo-treated patients became more DNCB-sensitive than at the first challenge, whereas five out of thirty-nine patients receiving levamisole continuously ( $P$ n.s.) and twenty-five out of forty-one patients receiving levamisole intermittently $(P<0 \cdot 00001)$ became more DNCB-sensitive (Table 2).

Forty-seven cancer patients treated with levamisole continuously or intermittently could be followed-up for more than one year. Of these patients, twenty-eight died, four in a group of sixteen patients who become more DNCB-sensitive during levamisole therapy, and twenty-four in a group of thirty-one patients with no increase in DNCB sensitivity during levamisole therapy $(P=0.001)$.

Lipofundin clearance test

As shown in Fig. 1, the lipid emulsion injected 


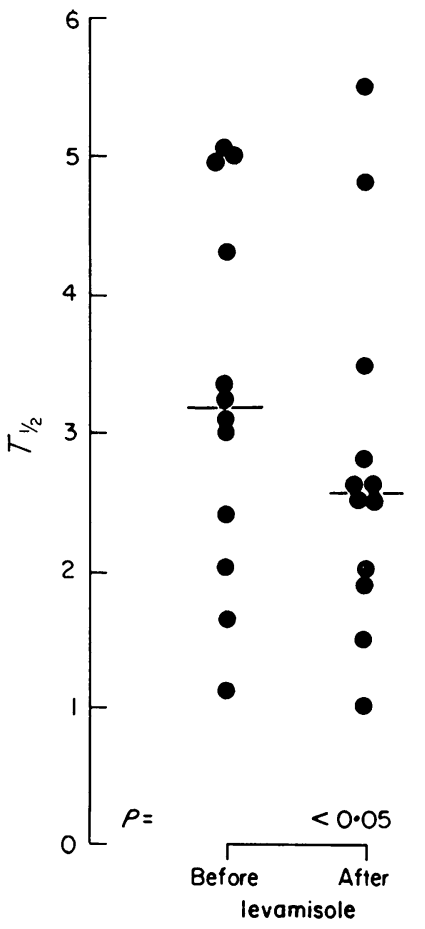

FIG. 1. The effect of levamisole on the half-life $\left(T_{1} / 2\right)$ of a lipid emulsion injected intravenously in twelve cancer patients.

in twelve cancer patients was cleared from the blood stream more rapidly after levamisole treatment (mean $T_{1 / 2}=2.53 \mathrm{~min}$ ) than before treatment (mean $T_{1 / 2}=$ $3.18 \mathrm{~min}$ ). This activation was significant at the $5 \%$ level, suggesting an effect of levamisole on the reticulo-endothelial system.

Although the twelve cancer patients reported here tolerated repeated injections of the lipid emulsion, this test produced, besides other side effects, severe respiratory difficulties in several other patients and is therefore not useful for clinical investigation.

\section{Serum complement}

As shown in Fig. 2, levamisole significantly elevated serum haemolytic complement activity in cancer patients $(P<0.00001)$. The haemolytic complement activity in the control group did not change significantly.

Intergroup differences also were significant $(P<0 \cdot 00001)$.

Serum complement components $\left(C_{3}, C_{4}\right.$ and $C_{19}$ did not change significantly in the levamisole- or placebo-treated groups.

Interesting is the correlation found between serum haemolytic complement activity and the

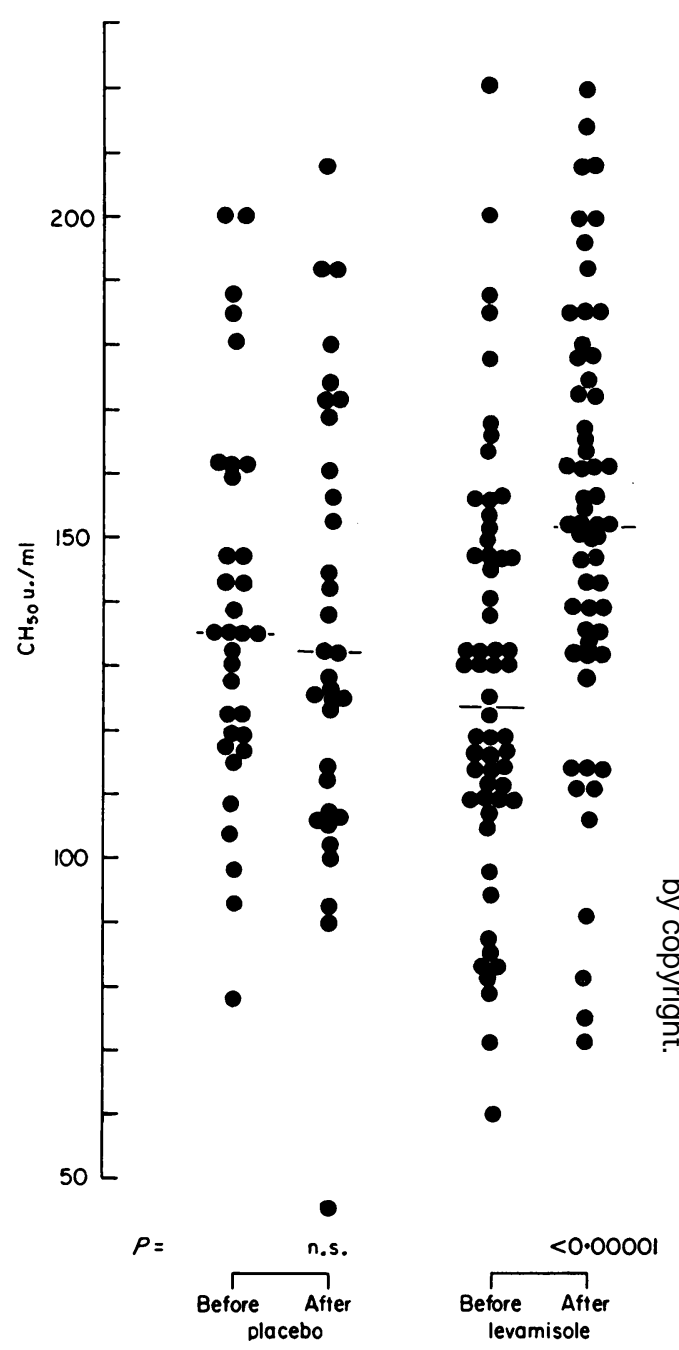

FIG. 2. The effect of 1-2 weeks of treatment with levamisole on haemolytic complement activity in sera of cancer patients.

$T_{1 / 2}$ in the lipofundin clearance test $(y=-7 \cdot 543 x+$ $1 \cdot 554, \mathrm{r}=-0.423, P<0.001)$.

\section{Immunoglobulins}

The immunoglobulins IgA, IgG and IgM did not change significantly after levamisole treatment.

\section{E-rosette forming cells}

In the placebo group the mean percentage of RFC was $57.2 \%$ when first tested and $58.1 \%$ in the second test. In the levamisole-treated group the mean percentage of RFC was $56.5 \%$ before treatment and $\stackrel{\Phi}{\oplus}$ $57.2 \%$ after treatment. Intra- and intergroup differences were not significant. However, when only 


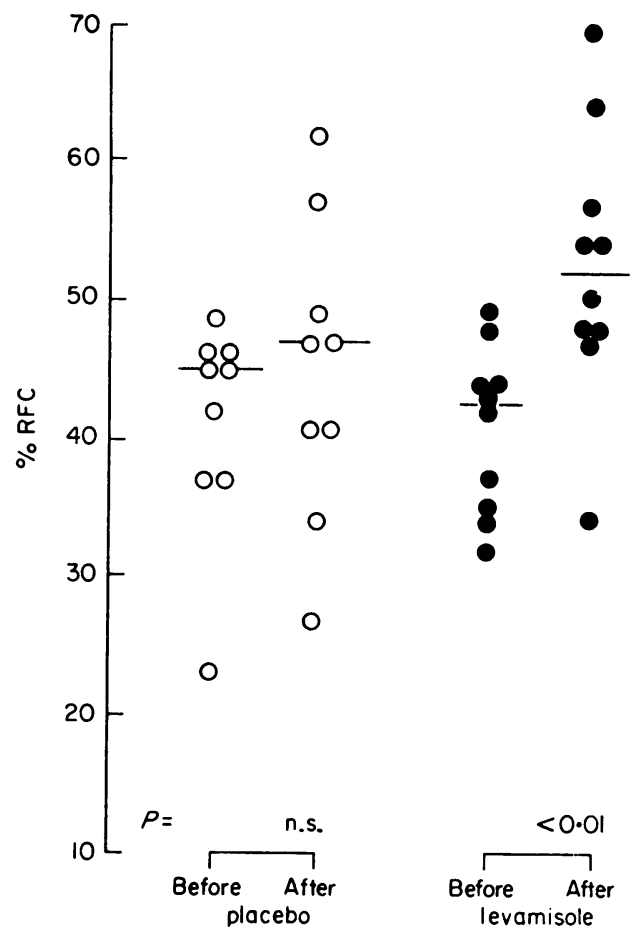

FIg. 3. The effect of levamisole treatment on low Erosette forming cells (RFC) in cancer patients.

the patients with low E-rosettes $(<50 \%$ being 2 standard deviations lower than the mean of eightyone healthy blood donors) were analysed, levamisole significantly enhanced low rosette formation $(P=$ 0.01 ), whereas in the placebo group RFC remained low (Fig. 3).

\section{Side effects}

The records of 213 levamisole-treated patients were analysed for possible side effects. In about one third of the patients one of the following complaints was noted: vomiting, tiredness, nausea, diarrhoea, bitter taste, insomnia, headache, dizziness and pruritus. However, the levamisole therapy did not have to be interrupted because of these complaints. Ten patients, receiving $150 \mathrm{mg}$ levamisole for 3 consecutive days every 14 days, showed a generalized skin rash with fever and itching. In five patients, the levamisole therapy was definitely stopped on their demand. In the other five patients, intermittent levamisole treatment was reinstituted when symptoms had disappeared and skin rashes did not reappear in four patients. However, the other patient showed recurrence of allergic reactions and developed granulocytopenia each time she took levamisole, but these symptoms disappeared in the levamisole-free periods. In this patient levamisole therapy was withdrawn.

\section{Discussion}

The above data show that levamisole therapy can restore delayed hypersensitivity reactions to PPD and enhance DNCB sensitivity in some cancer patients, which confirm other previous reports (Tripodi, Parks and Brugmans, 1973; Hirshaut et al., 1973; Levo, Rotter and Ramot, 1975; Rojas et al., 1976). Eilber and Morton (1970) have demonstrated that depressed sensitivity to DNCB in cancer patients is correlated with a bad prognosis and they suggest that tumour growth may be associated with defective cell-mediated immunity. The restoration or enhancement of defective delayed hypersensitivity reactions by levamisole may therefore be of benefit in cancer patients, and this is backed by the finding that patients in whom DNCB sensitivity increased during levamisole treatment had a better prognosis than patients in whom DNCB sensitivity did not change.

The complement system also plays an important role in the defence of the body and it has been previously shown that serum complement activity increases with progressing tumours contributing to the humoral defence of the integrity of the body (Verhaegen et al., 1976). It was observed that levamisole significantly increases haemolytic complement activity in cancer patients, thus potentiating the already enhanced humoral reaction to the tumour.

The lipofundin clearance test measures the phagocytic activity of the reticulo-endothelial system (Lemperlee, Reichelt and Denk, 1971). In cancer patients, levamisole enhanced the clearance of the lipid emulsion and concomitantly increased haemolytic complement activity. The enhancing effects of levamisole on the phagocytic activity of the reticuloendothelial system has also been shown in mice by Hoebeke and Franchi (1973).

The stimulation of the macrophage function by levamisole may explain its effects both on the complement system and on delayed hypersensitivity reactions. Complement components are synthetized by macrophages (Stecher, 1970) and macrophages play an important role in delayed hypersensitivity reactions (Mackaness, 1970; David, 1970; Asherson and Zembala, 1970). The enhancement of delayed hypersensitivity reactions by levamisole may also be due to its interaction with T-lymphocytes, as it was found that levamisole therapy enhances defective Erosette formation confirming the data from other experiments (Verhaegen et al., 1977a,b; Ramot et al. 1976; De Cock, De Cree and Verhaegen, 1977). Levamisole has also been reported as enhancing lymphoblast transformation (Chan and Simons, 1975; Chan, Lee and Simons, 1976; Lichtenfeld 
et al., 1976) and the release of lymphocyte mediators (Whitcomb, Merluzzi and Cooperband, 1976; Lieberman and Hsu, 1976; Golding et al., 1976).

\section{Acknowledgments}

We thank O. Vogels, L. Van der Veken, V. Roels and G. Bijnens for technical assistance; J. Dony for statistical analysis; and Gwen Badr for reviewing the manuscript.

\section{References}

AmERY, W.K. (1976) Double-blind levamisole trial in resectable lung cancer. Annals of the New York Academy of Sciences, 277, 260.

Anthony, H.M., Kirk, J.A., Madsen, K.E., Mason, M.K. \& Templeman, G.H. (1975) E and EAC rosetting lymphocytes in patients with carcinoma of bronchus. I. Some parameters of the test and of its prognostic significance. Clinical and Experimental Immunology, 20, 29.

Anthony, H.M., Templeman, G.H., Madsen, K.E. \& MASON, M.K. (1974) The prognostic significancy of DHS skin tests in patients with carcinoma of the bronchus. Cancer, 34, 1901.

Asherson, G.L. \& Zembala, M. (1970) Mononuclear Phagocytes (Ed. by Van Furth, R.), p. 495. Blackwell Scientific Publications, Oxford.

Bluming, A.Z. (1975) Current status of clinical immunotherapy. Cancer Chemotherapy Reports, 59, 901.

Brugmans, J., Schuermans, V., de Cock, W., Thienpont, D., Janssen, P., Verhaegen, H., VAN Nimmen, L., Louwagie, A.C. \& Stevens, E. (1973) Restoration of host defence mechanisms in man by levamisole. Life Sciences, 13, 1499.

Chan, S.H., Lee, S.N. \& Simons, M.J. (1976) Levamisole augmentation of lymphocyte hyporesponsiveness to phytohaemagglutinin in patients with pulmonary tuberculosis (39292). Proceedings of the Society for Experimental Biology and Medicine, 151, 716.

Chan, S.H. \& Simons, M.J. (1975) Levamisole and lymphocyte responsiveness. Lancet, i, 1246.

Cheema, A.R. \& Hersch, E.M. (1971) Patients survival after chemotherapy and its relationship in vitro lymphocyte blastogenesis. Cancer, 28, 851.

Chirigos, M.A., Fuhrman, F. \& Pryor, J. (1975) Prolongation of chemotherapeutically induced remission of a syngeneic murine leukemia by $\mathrm{L}-2,3,5,6$-tetrahydro-6phenylimidazo(2,1-B)thiazole hydrochloride. Cancer $R e$ search, 35, 927.

Chirigos, M.A., Pearson, J.W. \& Fuhrman, F.S. (1974) Effect of tumor load reduction on successful immunostimulation. Proceedings of the American Association for Cancer Research, 15, 116.

DAvid, J.R. (1970) Mononuclear Phagocytes (Ed. by Van Furth, R.), p. 486, Blackwell Scientific Publications, Oxford.

de Cock, W., de Cree, J. \& Verhaegen, H. (1977) Restoration by levamisole of histamine inhibited E-rosette formation of T-lymphocytes of patients with allergies, International Archives of Allergy and Applied Immunology, 54, 176.

Dellon, A.L., Potvin, C. \& Chretien, P.B. (1975) Thymusdependent lymphocyte levels in bronchogenic carcinoma: correlations with histology, clinical stage, and clinical course after surgical treatment. Cancer, 35, 687.

EILBER, F.R. \& MORTON, D.L. (1970) Impaired immunologic reactivity and recurrence following cancer surgery. Cancer, 25, 362.

Elhilali, M.M., Britton, S., Brosman, S. \& Fahey, J.L. (1976) Critical evaluation of lymphocyte functions in urological cancer patients. Cancer Research, 36, 132.

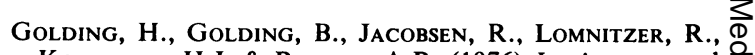
KOORNHOF, H.J. \& RABSON, A.R. (1976) In vitro reversal $\frac{\varrho}{c}$ of cellular unresponsiveness induced by levamisole. Clinical and Experimental Immunology, 26, 295.

Gross, R.L., Latty, A., Williams, E.A. \& Newberne, P.M. ज़ (1975) Abnormal spontaneous rosette formation and $\bar{C}$ rosette inhibition in lung carcinoma. New England Journal of Medicine, 292, 439.

Hirshaut, Y., Pinsky, C., Marquardt, H. \& Oettgen, $\overparen{\mathbb{D}}$ H.F. (1973) Effects of levamisole on delayed hyper- $Q$ sensitivity reactions in cancer patients (Abstract). Proceedings of the American Association for Cancer Research, 14, 109.

HoEbeKe, J. \& Franchi, G. (1973) Influence of tetramisole and its optical isomers on the mononuclear phagocytic $\vec{\omega}$ system. Effect on carbon clearance in mice. Journal of the Reticuloendothelial Society, 14, 317.

Lemperlee, G., Reichelt, M. \& Denk, S. (1971) The Reticuloendothelial System and Immune Phenomena (Ed. by

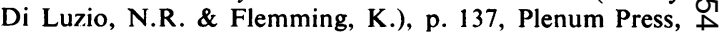
New York.

Levo, Y., Rotter, V. \& Ramot, B. (1975) Restoration of $\underset{\infty}{\infty}$ cellular immune response by levamisole in patients with Hodgkin's disease. Biomedicine, 23, 198.

Lichtenfeld, J.L., Desner, M.R., Wiernik, P.H. \& MARDINEY, M.R. (1976) The modulating effects of levamisole (NSC-177023) on human lymphocyte response in vitro. Cancer Treatment Reports, 60, 571.

Lieberman, R. \& Hsu, M. (1976) Levamisole-mediated restoration of cellular immunity in peripheral blood lymphocytes of patients with immunodeficiency diseases Clinical Immunology and Immunopathology, 5, 142.

Mackaness, G.B. (1970) Mononuclear Phagocytes (Ed. b Van Furth, R.), p. 478. Blackwell Scientific Publications Oxford.

Mancini, G., Carbonara, A.O. \& Heremans, J.F. (1965) Immunochemical quantitation of antigens by single radial immunodiffusion. Immunochemistry, 2, 235.

MAYER, M.M. (1971) Experimental Immunochemistry (Ed. by Kabat, E.A. \& Mayer, M.M.), 2nd edn, p. 133. Charles C. Thomas, Springfield.

Oettgen, H.F., Pinsky, C.M. \& Delmonte, L. (1976) Treatment of cancer with immunomodulators. Medical Clinics of North America (Symposium on Immunotherapy in Malignant Disease), p. 511. W. B. Saunders Co., Philadelphia.

Perk, K., Chirigos, M.A., Fuhrman, F. \& Pettigrew, H. (1975) Some aspects of host response to levamisole after chemotherapy in a murine leukemia. Journal of the National Cancer Institute, 54, 253.

Ramot, B., Biniaminov, M., Shoham, C.H. \& Rosenthal, E. (1976) The effect of levamisole on E-rosette-forming cells in vivo and in vitro in Hodgkin's disease. New England Journal of Medicine, 294, 809.

Renoux, G. \& Renoux, M. (1971) Effet immunostimulant d'un imidothiazole dans l'immunisation des souris contre l'infection par Brucella abortus. Comptes Rendus Hébdomadaires des Séances de l'Académie des Sciences, Paris, 272, 349.

Rojas, A.F., Feierstein, J.N., Mickiewicz, E., Glait, H. \& OLIVARI, A.J. (1976) Levamisole in advanced human breast cancer. Lancet, i, 211.

SiEgel, S. (1956a) Nonparametric Statistics for the Behavioral Sciences, p. 116. McGraw-Hill Book Co., Inc., New York.

Siegel, S. (1956b) Nonparametric Statistics for the Behavioral Sciences, p. 75. McGraw-Hill Book Co., Inc., New York. 
Stecher, V.J. (1970) Mononuclear Phagocytes (Ed. by Van Furth, R.), p. 133. Blackwell Scientific Publications, Oxford.

Suciu-Foca, N., Buda, J., McManus, J., Thiem, T. \& ReEmTsma, K. (1973) Impaired responsiveness of lymphocytes and serum-inhibitory factors in patients with cancer. Cancer Research, 33, 2373.

Symoens, J. \& Rosenthal, M. (1977) Levamisole in the modulation of the immune response: the current experimental and clinical state. Journal of the Reticuloendothelial Society, 21, 175.

Tripodi, D., Parks, L.C. \& Brugmans, J. (1973) Druginduced restoration of cutaneous delayed hypersensitivity in anergic patients with cancer. New England Journal of Medicine, 289, 354.

Twomey, P.L., Catalona, W.J. \& Chretien, P.B. (1974) Cellular immunity in cured cancer patients. Cancer, 33, 435 .

Verhaegen, H., de Cock, W. \& De Cree, J. (1977a) The effects of azathioprine and levamisole on rosette-forming cells of healthy subjects and cancer patients. Clinical and Experimental Immunology, 29, 311.

Verhaegen, H., de Cock, W., de Cree, J. \& Verbruggen, F. (1976) Increase of serum complement levels in cancer patients with progressing tumors. Cancer, 38, 1608.

Verhaegen, H., de Cree, J., de Cock, W. \& Verbruggen, F. (1973) Levamisole and the immune response. New England Journal of Medicine, 289, 1148.

Verhaegen, H., de Cree, J., de Cock, W. \& Verbruggen, F. (1977b) Restoration by levamisole of low E-rosetteforming cells in patients suffering from various diseases. Clinical and Experimental Immunology, 27, 313.

Whitcomb, M.E., Merluzzi, V.J. \& Cooperband, S.R. (1976) The effect of levamisole on human lymphocyte mediator production in vitro. Cellular Immunology, 21, 272.

Whitehead, R.A., Thatcher, J., Teasdale, C., Roberts, G.P. \& Hughes, L.E. (1976) T and B lymphocytes in breast cancer. Stage relationship and abrogation of $T$ lymphocyte depression by enzyme treatment in vitro. Lancet, i, 330.

Whittaker, M.G., Rees, K. \& Clark, C.G. (1971) Reduced lymphocyte transformation in breast cancer. Lancet, $\mathbf{i}$, 892.

Wybran, J. \& FudenberG, H.H. (1973) Thymus-derived rosette-forming cells in various human disease states: cancer, lymphoma, bacterial and viral infections, and other diseases. Journal of Clinical Investigation, 52, 1026. 